\begin{tabular}{|l|c|c|c|r|}
\hline $\begin{array}{l}\text { Cuadernos de Investigación Geográfica } \\
\text { Geographical Research Letters }\end{array}$ & 2018 & N $^{\circ} 44(2)$ & pp. 387-395 & $\begin{array}{r}\text { ISSN 0211-6820 } \\
\text { eISSN 1697-9540 }\end{array}$ \\
\hline
\end{tabular}

\title{
THE RELEVANCE OF HYDROLOGICAL RESEARCH IN SMALL CATCHMENTS - A PERSPECTIVE FROM LONG- TERM MONITORING SITES IN EUROPE
}

\author{
J. LATRON ${ }^{1 *}$, N. LANA-RENAULT ${ }^{2}$ \\ ${ }^{1}$ Institute of Environmental Assessment and Water Research (IDAEA-CSIC), \\ Jordi Girona, 18-26, 08034 Barcelona, Spain. \\ ${ }^{2}$ Área de Geografía Física, Departamento de Ciencias Humanas, Universidad de La Rioja, \\ Edificio Luis Vives, 26004 Logroño, Spain.
}

\begin{abstract}
The usefulness of small $\left(<10 \mathrm{~km}^{2}\right)$ catchments has been repeatedly recognized during the recent history of hydrological research. This foreword to the special issue of Cuadernos de Investigación Geográfica - Geographical Research Letters devoted to long term hydrological research in small catchment in Europe highlights the main reasons for promoting the small catchment approach and revises its growing use, starting with the first catchment studies in Switzerland for forest management purposes, and followed by the development of more interdisciplinary research programs that used small catchments as field laboratories, long-term observatories, sites for method and model validation, and places for training young researchers. The volume includes nine contributions concerning studies carried out in long term monitoring sites in several European countries and aims at showing the relevance of the small catchment approach in hydrological research in Europe.
\end{abstract}

La importancia de la investigación hidrológica en pequeñas cuencas - Una perspectiva a partir de sitios instrumentados a largo plazo en Europa

RESUMEN. La utilidad de los estudios en pequeñas $\left(<10 \mathrm{~km}^{2}\right)$ cuencas ha sido reiteradamente reconocida a lo largo de la historia de la investigación hidrológica. Este prólogo al número especial de Cuadernos de Investigación Geográfica - Geographical Research Letters sobre investigaciones hidrológicas a largo plazo en pequeñas cuencas en Europa destaca las principales razones para fomentar los estudios en pequeñas cuencas y revisa su creciente uso, empezando por los estudios de cuenca llevados a cabo en Suiza con fines de gestión forestal, seguidos por el desarrollo de programas de investigación más interdisciplinares que utilizaron las cuencas como laboratorios de campo, observatorios a largo plazo, lugares para validar métodos y modelos, y para formar a jóvenes investigadores. Este volumen incluye nueve contribuciones sobre estudios llevados a cabo en sitios instrumentados a largo plazo en varios países europeos y pretende mostrar 
la relevancia del uso de pequeñas cuencas en la investigación hidrológica en Europa.

Key words: small catchment, hydrological research, Europe.

Palabras clave: pequeña cuenca, investigación hidrológica, Europa.

Received: 13 December 2017

Accepted: 2 January 2018

*Corresponding author: Jérôme Latron, Institute of Environmental Assessment and Water Research (IDAEA-CSIC), Jordi Girona, 18-26, 08034 Barcelona, Spain. E-mail address: jerome.latron@idaea.csis.es

Almost 50 years ago, Hewlett et al. (1969) noted that observations of hydrological processes in small research catchments contribute knowledge essential to both land management and the science of hydrology. Despite its limitations, which are partly related to inability to control the natural environment (Ambroise, 1994), the usefulness of small $\left(<10 \mathrm{~km}^{2}\right)$ catchment research has been repeatedly recognized during recent decades (e.g., Hewlett et al., 1969; Ward, 1971; Dubreuil, 1989; Bonell, 1993; Tetzlaff et al., 2017). Recent reports (Burt and McDonnell, 2015; Beven, 2016; Tetzlaff et al., 2017) have highlighted the invaluable role of field studies in experimental catchments and the resulting long-term data, and emphasized that this approach is increasingly needed, particularly in the context of increasing water demand, rapid changes in land uses, and uncertainties in climate change projections.

There are many reasons to promote the small catchment research approach. Small catchments enable high density and quality measurements for understanding the complexities of hydrological processes. Most of the development of fundamental hydrological concepts has come from field observations in small research catchments. For instance, the "variable source area" hypothesis for storm runoff generation (described by Hewlett, 1961), and the "partial area" concept proposed by Betson (1964) were based on field investigations in a small research catchment in North Carolina, USA. Critical findings on macropore flow mechanisms in runoff generation, carried out by Mosley (1979), Pearce et al. (1986), and Sklash et al. (1986) were also based on field data collected in several small catchments in the Maimai study area in New Zealand. Additional examples of fundamental hydrological research on runoff generation processes have been described by Burt and McDonnell (2015), and most of these were based on field studies undertaken in small catchments. Furthermore, monitoring of small catchments favors the development of novel measurement technologies that open new and previously unconceivable opportunities for investigating natural processes. For instance, geophysical techniques are used to define the subsoil structure and better understand subsurface flows (e.g. Preti et al., 2017), and new tracers including diatoms (Pfister et al., 2017) and rare earth elements (Masselink et al., 2017) are being used to track and study flow sources and pathways. 
Hydrological science is dependent on a range of measurement techniques (Beven, 2016), and the sometimes-accepted notion that simulations could replace field experimentation has been consistently criticized (Hewlett et al., 1969; Philip, 1991; Burt and McDonnell, 2015; Beven, 2016). The datasets derived from small catchments are rich resources for model development and testing. For instance, as noted by Tetzlaff et al. (2017), the development of influential models including TOPMODEL and SHE was possible because of the high quality data derived from seminal studies in the Plynlimon catchment (Wales, UK). Several decades ago, Hewlett et al. (1969) noted that modeling studies are really useful only if they are based on high quality input data. The acquisition and analysis of field data remains essential, despite occasionally being reported to be of little value (Grayson et al., 1992; Ambroise, 1994). Burt and McDonnell (2015) noted that despite the perception that field hydrology is on the decline (i.e., the number of model-based vs. field data-based publications in hydrological journals), field-derived insights into the age, origin, and pathway of water in headwaters are increasingly needed, and Beven (2016) noted that hydrological science is still in need of research into fundamental processes. While some prioritize this research in the "critical zone" (the "Earth's dynamic skin", Grant and Dietrich, 2017) and others insist on the relevance of ecohydrological interfaces (Krause et al., 2017), new "outrageous hydrological hypotheses" are clearly needed (Burt and McDonnell, 2015), particularly those putting flow and transport into a consistent coherent framework (McDonnell and Beven, 2014). If observations and field measurements and modeling efforts are indispensable and complementary, they should be jointly conducted from the outset, but this is rarely the case (Ambroise, 1999). Indeed, many authors have identified a need for greater synergy between field studies and modeling (e.g., Dunne, 1983; Christophersen and Neal, 1990; DeCoursey, 1991; Grayson et al., 1992; Becker et al., 1999; Seibert and McDonnell, 2002). In today's changing world, this synergy must necessarily rely on small research catchments, using them as a field-model interface.

The essential role and importance of small research catchments was clearly highlighted by Hewlett et al. (1969), who noted that "if we wish to manage watersheds, we shall have to study watersheds". The knowledge gained in catchment research has been used to answer practical questions and help in decision making. Early research in paired watersheds (Bates and Henry, 1928; Hoover, 1944) provided sound evidence that forest cutting increases water yield and forest regrowth reduces it, which was essential information for management of watersheds by the US Forest Services. More recently, research in the Krycklan catchment (Sweden) has revealed the important regulatory role of the riparian zone on water and solute fluxes in boreal environments (Tiwari et al., 2016 cited in Tetzlaff et al., 2017), and has led to new policies for riparian protection in commercial forests (Tetzlaff et al., 2017). Small catchments have often been considered to be "outdoor laboratories" for monitoring changes in environmental variables (Schumman et al., 2010). Even if much knowledge has accumulated on runoff mechanisms, there remains an urgent need to understand these processes in a changing environment (Burt and McDonnell, 2015). Thus, long-term data series from research catchments are needed to detect trends and changes in the system response, associated with changes in land use and climate. In addition, long-term data series enable the detection and understanding of extreme events including floods and droughts, which are the main concern of policy makers because they are the hydrological events having the greatest impacts (Tetzlaff $e t$ 
$a l ., 2017)$. However, collecting long-term data series requires long-term investment and a high level of commitment, both of which are challenging.

The use of small catchments in hydrological research dates to the 1900s and the comparative monitoring of the Sperbelgraben (forest) and Rappengraben (grassland) catchments, in studies of the effect of vegetation cover on the hydrological regime and flood dynamics in Swiss mountain areas (Engler, 1919 cited in Keller, 1988; Stähli et al., 2011). Several years later the first experimental paired watersheds were established for the Wagon Wheel Gap Experiment in Colorado, USA (Bates and Henry, 1928, cited in Hewlett, 1982). In the early 1930s the creation of the Coweeta Hydrology Laboratory in North Carolina (Swank and Crossley, 1988) confirmed the growing importance of small research catchments; two main catchments involved comprise a total area of $22 \mathrm{~km}^{2}$ and 26 sub-catchments, and have been the basis of a detailed long-term study of the hydrological consequences of modification of vegetation cover (Swank et al., 1988). In Europe, since 1948 the catchments of the Harz mountains (Germany) have facilitated study of the influence of reforestation on the water balance (Liebscher and Wilke, 1981 cited in Keller, 1988).

Despite their increasing number, catchment studies followed an empirical approach until the 1960 s, favored by the need to obtain results that were applicable from a management perspective. Although this approach sometimes contributed to progress in understanding of catchment hydrological behavior (e.g., Hursh and Brater, 1941; Cappus, 1960; Hewlett, 1961; Tsukamoto, 1963), it has not favored the detailed study of hydrological processes at the catchment scale. At the beginning of the $1960 \mathrm{~s}$ the problems encountered in the generalization of results, skepticism about catchment representativeness, and the cost of monitoring led some authors (e.g., Ackermann 1966; Reynolds and Leyton, 1967 cited in Hewlett et al., 1969) to question use of the small catchment approach. At that time, the perception that there remained "complete ignorance of the causes and precise effects of the different components of the hydrological cycle" after more than 30 years of research (Slivitzsky and Hendler, 1964 cited in Hewlett et $a l ., 1969)$ contributed to questions about the value of continued use of small catchments for hydrological research.

In addition to this situation, increasing awareness of the need to know and understand hydrological and/or associated physical, chemical, and biological processes led to the development of interdisciplinary research programs adopting a dynamic and modeling approach, using small catchments as field laboratories. The Hubbard Brook catchments in the USA, instrumented in 1955, were one of the first interdisciplinary experimental sites, and enabled detailed study of hydrogeochemical balances in the 1960s (Likens et al., 1977). At approximately the same time the UNESCO International Hydrological Decade (1965-1974) was promoting international collaboration in hydrology. This contributed to the development of many small catchments for hydrological research worldwide, and encouraged more multidisciplinary research studies; for example, those initiated in 1971 in the catchments of the Krofdorf Forest research area in Germany (Brechtel and Führer, 1991). As noted by Ambroise (1994), this considerable expansion of the small catchment approach facilitated the emergence of the hillslope hydrology concept (Kirkby, 1978), and identification of the main hydrological processes and factors. 
Today the concept of the small research catchment seems more and more relevant to a diversity of environmental issues beyond hydrology, and as noted by Tetzlaff et al. (2017), some well-monitored catchments have been included in national or international networks including: the Long-Term Ecological Research (LTER) network, with sites distributed in the USA (Knapp et al., 2012; Collins and Childers, 2014) and Europe (Mirtl, 2010); the Critical Zone observatories in the USA (White et al., 2015); and the German Terrestrial Environmental Observatories (TERENO) network (Forschungszentrum Jülich et al., 2016). Through their multiple roles including as field laboratories, longterm observatories, sites for method and model validation, and places for training young researchers (Leclerc, 1992; Ambroise, 1994), small research catchments constitute an essential tool in the study and management of the natural environment.

This volume of Cuadernos de Investigación Geográfica-Geographical Research Letters presents contributions concerning studies carried out at eight long-term monitoring sites in Europe. The objective is to stress the relevance of long-term research in small catchments for obtaining meaningful and key hydrological results. These contributions represent only a small subset from among the numerous small catchment research projects that are being, or have been undertaken throughout the continent. A ninth contribution discusses the role of international activities in promoting and disseminating research based on small catchments, in particular the ERB (Euro-Mediterranean Network of Experimental and Representative Basins) network, which was created in 1986 to organize and facilitate the exchange of data and knowledge, and to promote cooperation in international research programs (Holzmann, 2018).

The catchments included in this volume are located in a wide variety of environments, including high elevation (Holko et al., 2018; Zuecco et al., 2018), pre-alpine (van Meerveld et al., 2018) and sub-Mediterranean (Lana-Renault et al., 2018; Llorens et al., 2018) mountain areas; in rural landscapes under both humid (Gascuel-Odoux et al., 2018) and Mediterranean (Schnabel et al., 2018) conditions; and in environments in transition between arid and semiarid climate conditions (Rodríguez-Caballero et al., 2018). Most of the contributions focus on understanding of runoff generation mechanisms in the studied environments, using various types of data (hydrometric data, isotopes, stream chemistry) and approaches (analysis of thresholds, hysteresis, hydrological connectivity, controlling factors, and hydrological modeling). They also show the value of having a dense measurement network and applying complementary techniques to better define a conceptual model of runoff generation processes (van Meerveld et al., 2018; Zuecco et al., 2018). Some contributions also consider associated hydrological processes including rainfall partitioning and forest transpiration (Llorens et al., 2018), biochemical cycles (Gascuel-Odoux et al., 2018) and sediment transport (Llorens et al., 2018; RodríguezCaballero et al., 2018). Others consider more technical aspects, including evaluation of methods for determining event and pre-event water in flood events (Holko et al., 2018). These studies provide data enabling assessment of the implications of global change for catchment water resources and soil conservation (e.g., Lana-Renault et al., 2018). In addition, they show the relevance of long-term monitoring sites for (interdisciplinary) environmental research and management (Gascuel-Odoux et al., 2018; Holzmann, 2018), especially in areas having high and very high rainfall variability (Rodríguez-Caballero et al., 2018; Schnabel et al., 2018). 
Finally, we conclude this foreword by acknowledging the efforts of the authors and reviewers of the articles included in this special volume, which highlights the essential role of long-term small catchment monitoring in hydrological research in Europe.

\section{References}

Ambroise, B. 1994. Du BVRE, bassin versant représentatif et expérimental, au BVR, bassin versant de recherche. In: D. Houi., J.L. Verrel (Eds.), Du Concept de BVRE à celui de Zone Atelier dans les Recherches menées en Eaux Continentales, Actes du Séminaire National Hydrosystèmes, Paris, pp. 11-24.

Ambroise, B. 1999. La Dynamique du Cycle de l'Eau dans un Bassin Versant. -Processus, Facteurs, Modèles. ${ }^{*} \mathrm{H}^{*} \mathrm{G} * \mathrm{~A}, 200$ pp.

Bates, C.G., Henry, A.J. 1928. Forest and streamflow experiment at Wagon Wheel Gap, Colorado. Monthly Weather Review Supplement 30.

Becker, A., Günter, A., Katzenmaier, D. 1999. Required integrated approach to understand runoff generation and flow-path dynamics in catchments. In: C. Leibundgut, J. McDonnell, G. Schultz, (Eds.), Integrated Methods in Catchment Hydrology-Tracer, Remote Sensing and New Hydrometric Techniques. IAHS Publication 258, 3-9.

Betson, R.P. 1964. What is watershed runoff? Journal of Geophysical Research 69 (8), 1541-1552. https://doi.org/10.1029/JZ069i008p01541.

Beven, K. 2016. Advice to a young hydrologist. Hydrological Processes 30, 3578-3582. https:// doi.org/10.1002/hyp.10879.

Bonell, M. 1993. Progress in the understanding of runoff generation dynamics in forests. Journal of Hydrology 150, 217-275. https://doi.org/10.1016/0022-1694(93)90112-M.

Brechtel, H.M., Führer, H.W. 1991. Water yield control in beech forest. A paired watershed study in the Krofdorf forest research area. In: G. Kienitz, P.C.D. Milly, M.Th. Van Genuchten, D. Rosbjerg, W.J. Shuttleworth (Eds.), Hydrological Interactions Between Atmosphere, Soil and Vegetation. IAHS Publication 204, 477-484.

Burt, T.P., McDonnell, J.J. 2015. Whither field hydrology? The need for discovery science and outrageous hydrological hypotheses. Water Resources Research 51, 5919-5928. https://doi. org/10.1002/2014WR016839.

Cappus, P. 1960. Bassin expérimental d'Alrance. Étude des lois de l'écoulement. Application au calcul et à la prévision des débits. La Houille Blanche A, 493-520. https://doi.org/10.1051/ $\mathrm{lhb} / 1960007$.

Christophersen, N., Neal, C. 1990. Linking hydrological, geochemical, and soil chemical processes on the catchment scale: An interplay between modeling and field work. Water Resources Research 26 (12), 3077-3086. https://doi.org/ 10.1029/WR026i012p03077.

Collins, S.L., Childers, D.L. 2014. Long-Term Ecological Research and Network-Level Science. EOS Transactions American Geophysical Union 95 (33), 293-294. https://doi. org/10.1002/2014EO330001.

DeCoursey, D.G. 1991. Mathematical models: Research tools for experimental watersheds. In: D.S. Bowles, P.E. O'Connell (Eds.), Recent Advances in the Modelling of Hydrologic Systems. NATO ASI Series C, Vol. 345, Kluwer Academic Publ, pp. 591-612.

Dubreuil, P.L. 1989. Pour un suivi à long terme de l'évolution des ressources en eau grâce à un réseau européen de bassins de référence. Hydrogéologie 2, 111-114.

Dunne, T. 1983. Relation of field studies and modeling in the prediction of storm runoff. Journal of Hydrology 65, 25-48. https://doi.org/10.1016/0022-1694(83)90209-3. 
Forschungszentrum Jülich, Helmholtz Centre for Environmental Research, Karlsruhe Institute of Technology, Helmholtz Zentrum München, German Aerospace Center, German Research Centre for Geosciences. 2016. TERENO: German network of terrestrial environmental observatories. Journal of Large-Scale Research Facilities 2, A52. http://doi.org/10.17815/ jlsrf-2-98.

Gascuel-Odoux, C. Fovet, O., Gruau, G., Ruiz, L., Merot, P. 2018. Evolution of scientific questions over 50 years in the Kervidy-Naizin catchment: from catchment hydrology to integrated studies of biogeochemical cycles and agroecosystems in a rural landscape. Cuadernos de Investigación Geográfica - Geographical Research Letters 44 (2), 535-555. https://doi. org/10.18172/cig.3383.

Grant, G.E., Dietrich, W.E. 2017. The frontier beneath our feet. Water Resources Research 53 (4), 2605-2609. https://doi.org/10.1002/2017WR020835.

Grayson, R.B., Moore, I.D., McMahon, T.A. 1992. Physically based hydrological modelling 2. Is the concept realistic? Water Resources Research 28 (10), 2659-2666. https://doi. org/10.1029/92WR01259.

Hewlett, J.D. 1961. Watershed management. In: USDA Forest Service Annual Report, Southeast Forest Experimental Station, Ashville, NC, pp. 61-66.

Hewlett, J.D. 1982. Principles of forest hydrology. University of Georgia Press, 183 pp.

Hewlett, J.D., Lull, H.W., Reinhart, K.G. 1969. In defense of experimental watersheds. Water Resources Research 5 (1), 306-316. https://doi.org/10.1029/WR005i001p00306.

Holko, L., Bičárová, S., Hlavčo, J., Danko, M., Kostka, Z. 2018. Isotopic hydrograph separation in two small mountain catchments during multiple events. Cuadernos de Investigación Geográfica - Geographical Research Letters 44 (2), 453-473. https://doi.org/10.18172/ cig.3344.

Holzmann, H. 2018. Status and perspectives of hydrological research in small basins in Europe. Cuadernos de Investigación Geográfica - Geographical Research Letters 44 (2), 601-614. https://doi.org/10.18172/cig.3406.

Hoover, M. 1944. Effect of removal forest vegetation upon water-yields. EOS Transactions American Geophysical Union 25, 969-977. https://doi.org/10.1029/TR025i006p00969.

Hursh, C.R., Brater, E.F. 1941. Separating storm-hydrographs from small drainage-areas into surface- and subsurface-flow. EOS Transactions American Geophysical Union 22, 863-871. https://doi.org/10.1029/TR022i003p00863.

Keller, H.M. 1988. European experiences in long-term forest hydrology research. In: W.T. Swank, D.A. Crossley Jr. (Eds.), Forest Hydrology and Ecology at Coweeta. Ecological Studies, Vol. 66, Springer-Verlag, pp. 407-414.

Kirkby, M.J. (Ed.) 1978. Hillslope Hydrology. Wiley-Interscience Publ., 389 pp.

Knapp, A.K., Smith, M.D, Hobbie, S.E., Collins, S.L., Fahey, T.J., Hansen, G.J.A., Landis, D.A., La Pierre, K.J., Melillo, J.M., Seastedt, T.R., Shaver, G.R., Webster, J.R. 2012. Past, present, and future roles of long-term experiments in the LTER Network. BioScience 62, 377-389. https://doi.org/10.1525/bio.2012.62.4.9.

Krause, S., Lewandowski, J., Grimm, N.B., Hannah, D.M., Pinay, G., McDonald, K., Martí, E., Argerich, A., Pfister, L., Klaus, J., Battin, T., Larned, S.T., Schelker, J., Fleckenstein, J., Schmidt, Ch., Rivett, M.O., Watts, G., Sabater, F., Sorolla, A., Turk, V. 2017. Ecohydrological interfaces as hot spots of ecosystem processes. Water Resources Research 53, 6359-6376. https://doi.org/10.1002/2016WR019516.

Lana-Renault, N., López-Vicente, M., Nadal-Romero, E., Ojanguren, R., Llorente, J.A., Errea, P., Regüés, D., Ruiz-Flaño, P., Khorchani, M., Arnaez, J., Pascual, N. 2018. Catchment based hydrology under post farmland abandonment scenarios. Cuadernos de Investigación 
Geográfica - Geographical Research Letters 44 (2), 503-534. https://doi.org/10.18172/ cig.3475.

Leclerc, L.A. 1992. Recherche et développement sur la gestion des eaux: La politique des bassins versants représentatifs expérimentaux (BVRE). Hydrogéologie 4, 133-137.

Likens, G.E., Bormann, F.H., Pierce, R.S., Eaton, J.S., Johnson, N.M. 1977. Biogeochemistry of a Forested Ecosystem. Springer-Verlag, 146 pp.

Llorens, P., Gallart, F., Cayuela, C., Roig-Planasdemunt, M., Casellas, E., Molina, A.J., Moreno De Las Heras, M., Bertran, G., Sánchez-Costa, E., Latron, J. 2018. What have we learnt about Mediterranean catchment hydrology? 30 years observing hydrological processes in the Vallcebre research catchments. Cuadernos de Investigación Geográfica - Geographical Research Letters 44 (2), 475-501. https://doi.org/10.18172/cig.3432.

Masselink, R.J.H., Temme, A.J.A.M., Giménez, R., Casalí, J., Keesstra, S.D. 2017. Assessing hillslope-channel connectivity in an agricultural catchment using rare-earth oxide tracers and random forests models. Cuadernos de Investigación Geográfica - Geographical Research Letters 43 (1), 19-39. https://doi.org/10.18172/cig.3169.

McDonnell, J.J., Beven, K. 2014. Debates-The future of hydrological sciences: A (common) path forward? A call to action aimed at understanding velocities, celerities, and residence time distributions of the headwater hydrograph. Water Resources Research 50, 5342-5350. https:// doi.org/10.1002/2013WR015141.

Mirtl, M. 2010. Introducing the Next Generation of Ecosystem Research in Europe: LTER-Europe's Multi-Functional and Multi-Scale Approach. In: F. Müller, C. Baessler, H. Schubert, S. Klotz (Eds.), Long-Term Ecological Research. Springer, Dordrecht. https://doi.org/10.1007/97890-481-8782-9_6.

Mosley, M.P. 1979. Streamflow generation in a forested watershed, New Zealand. Water Resources Research 15 (4), 795-806. https://doi.org/10.1029/ WR015i004p00795.

Pearce, A.J., Stewart, M.K., Sklash, M.G. 1986. Storm runoff generation in humid headwater catchments: 1. Where does the water come from? Water Resources Research 22 (8), 12631272. https://doi.org/10.1029/WR022i008p01263.

Pfister, L. Wetzel, C.E., Klaus, J., Martínez-Carreras, J., Antonelli, M., Teuling, A.J., McDonnell, J.J. 2017. Terrestrial diatoms as tracers in catchment hydrology: a review. WIREs Water 4, e1241. https://doi.org/10.1002/wat2.1241.

Philip, J.R. 1991. Soils, natural science and models. Soil Science 151, 91-98.

Preti, F., Guastini,E., Penna, D., Dani, A., Cassiani, G., Boaga, J., Deiana, R., Romano, N., Nasta, P., Palladino, M., Errico, A., Giambastiani, Y., Trucchi, P., Tarolli, P. 2017. Conceptualization of water flow pathways in agricultural terraced landscapes. Land Degradation \& Development. https://doi.org/10.1002/ldr.2764.

Rodríguez-Caballero, E., Lázaro, R., Cantón, Y., Puigdefábregas, J., Solé-Benet, A. 2018. Longterm hydrological monitoring in arid-semiarid Almería, SE Spain. What have we learned? Cuadernos de Investigación Geográfica - Geographical Research Letters 44 (2), 581-599. https://doi.org/10.18172/cig.3462.

Schnabel, S., Lozano Parra, J., Gómez-Gutiérrez, A., Alfonso-Torreño, A. 2018. Hydrological dynamics in a small catchment with silvopastoral land use in SW Spain. Cuadernos de Investigación Geográfica - Geographical Research Letters 44 (2), 557-580. https://doi. org/10.18172/cig.3378.

Schumann, S., Schmalz, B., Meesenburg, H., Schröder, U. (Eds.) 2010. Status and Perspectives of Hydrology in Small Basins. Results of the International Workshop in Goslar-Hahnenklee, 2009 and Inventory of Small Hydrological Research Basins. IHP/HWRP-Berichte 10, Koblenz, Germany. 
Seibert, J., McDonnell, J.J. 2002. On the dialog between experimentalist and modeler in catchment hydrology: Use of soft data for multicriteria model calibration. Water Resources Research 38 (11), 1241. https://doi.org/10.1029/2001WR000978.

Sklash, M.G., Stewart, M.K., Pearce, A.J. 1986. Storm runoff generation in humid headwater catchments: 2. A case study of hillslope and low-order stream response. Water Resources Research 22 (8), 1273-1282. https://doi.org/10.1029/WR022i008p01273.

Stähli, M., Badoux, A., Ludwig, A., Steiner, K., Zappa, M., Hegg, Ch. 2011. One century of hydrological monitoring in two small catchments with different forest coverage. Environmental Monitoring and Assessment 174, 91-106. https://doi.org/10.1007/s10661010-1757-0.

Swank W.T., Crossley Jr, D.A. (Eds.) 1988. Forest Hydrology and Ecology at Coweeta. Ecological Studies, Vol. 66, Springer-Verlag, 512 pp.

Swank, W.T., Swift Jr, L.W., Douglass, J.E. 1988. Streamflow changes associated with forest cutting, species conversions, and natural disturbances. In: W.T. Swank, D.A. Crossley Jr (Eds.), Forest Hydrology and Ecology at Coweeta. Ecological Studies, Vol. 66, SpringerVerlag, pp. 297-312.

Tetzlaff, D., Carey, S.K., McNamara, J.P., Laudon, H., Soulsby, C. 2017. The essential value of long-term experimental data for hydrology and water management. Water Resources Research 53 (4), 2598-2604. https://doi.org/10.1002/2017WR020838.

Tiwari, T., Lundström, J., Kuglerova, L., Laudon, L., Öhman, K., Ågren, A.M. 2016. Cost of riparian buffer zones: A comparison of hydrologically adapted site-specific riparian buffers with traditional fixed widths. Water Resources Research 52, 1056-1069. https://doi. org/10.1002/2015WR018014.

Tsukamoto, Y. 1963. Storm Discharge from an Experimental Watershed. Journal of the Japanese Forestry Society 45 (6), 186-190. https://doi.org/10.11519/jjfs1953.45.6_186.

van Meerveld, I.H.J., Fischer, B.M.C, Rinderer, M., Stähli, M., Seibert, J. 2018. Runoff generation in a pre-alpine catchment: a discussion between a tracer and a shallow groundwater hydrologist. Cuadernos de Investigación Geográfica - Geographical Research Letters 44 (2), 429-452. https://doi.org/10.18172/cig.3349.

Ward, R.C. 1971. Small Watershed Experiments - An appraisal of concepts and research developments. University of Lull Printers Ltd, $254 \mathrm{pp}$.

White, T., Brantley, S., Banwart, S., Chorover, J., Dietrich, W., Derry, L., Lohse, K., Anderson, S., Aufdendkampe, A., Bales, R., Kumar, P., Richter, D., McDowell, B. 2015. The role of critical zone observatories in critical zone science. In: J.R. Giardino, C. Houser (Eds.), Developments in Earth Surface Processes, vol. 19, pp. 15-78, Elsevier. https://doi.org/10.1016/B978-0-44463369-9.00002-1.

Zuecco, G., Penna, D., Borga. M. 2018. Runoff generation in mountain catchments: long-term hydrological monitoring in the Rio Vauz catchment, Italy. Cuadernos de Investigación Geográfica - Geographical Research Letters 44 (2), 397-428. https://doi.org/10.18172/ cig.3327. 